\title{
PENERAPAN STRATEGI SCAFFOLDING PADA PEMBELAJARAN PEMROGRAMAN WEB DI SMK KARTIKA WIRABUANA 1
}

\author{
Udin Sidik Sidin \\ Fakultas Teknik Universitas Negeri Makassar \\ udin.sidik.sidin@unm.ac.id
}

\begin{abstract}
ABSTRAK
Penelitian ini bertujuan untuk mengetahui hasil belajar dan respon siswa terhadap penerapan strategi scaffolding pada pembelajaran pemrograman web siswa kelas 10 TKJ (Teknik Komputer Jaringan) SMK (Sekolah Menengah Kejuruan) Kartika Wirabuana 1. Penelitian ini merupakan penelitian pre-eksperimental dalam bentuk pretest posttest design dengan jumlah populasi 74 orang dan seluruh populasi digunakan sebagai sampel. Data diperoleh dengan teknik angket dan tes. Uji instrumen menggunakan uji validitas dengan korelasi Product Moment Pearson dan reliabilitas dengan Alpha Cronbach. Hasil penelitian menunjukkan bahwa respon siswa terhadap penerapan strategi scaffolding dalam pembelajaran berada pada kategori baik. Penerapan strategi scaffolding dapat mempengaruhi hasil belajar siswa pada mata pelajaran pemrograman web di Jurusan TKJ SMK Kartika Wirabuana 1. Hal ini ditunjukkan oleh perbandingan rata-rata hasil posttest yang lebih tinggi daripada rata-rata hasil pretest dengan rentangan perbedaan yang cukup tinggi.
\end{abstract}

Kata Kunci : Strategi Scaffolding, Pemrograman Web

\section{PENDAHULUAN}

Pendidikan memiliki peran penting dalam proses berkembangnya pemikiran seseorang ke arah yang lebih baik. Sesuai dengan pendapat Hamalik (2004:79) yang menyebutkan bahwa pendidikan merupakan suatu proses dalam rangka mempengaruhi siswa agar dapat menyesuaikan diri sebaik mungkin terhadap lingkungannya. Siswa yang dapat menyesuaikan diri dengan lingkungannya akan memperoleh perubahan yang akan berfungsi di kehidupan bermasyarakat.

Meningkatkan kualitas pendidikan merupakan tujuan yang diharapkan dalam pembangunan Pendidikan Nasional di Indonesia. Hal ini sesuai yang diterapkan dalam Undang-Undang No. 20 Tahun 2003 tentang Sistem Pendidikan Nasional pasal 3 berbunyi: "Pendidikan nasional berfungsi mengembangkan kemampuan dan membentuk watak sertaperadaban bangsa yang bermartabat dalam rangka mencerdaskan kehidupan bangsa,bertujuan untuk berkembangnya potensi peserta didik agar menjadi manusia yang berimandan bertakwa kepada Tuhan Yang Maha Esa, berakhlak mulia, sehat, berilmu, cakap, kreatif, mandiri, dan menjadi warga negara yang demokratis serta bertanggung jawab". Keberadaan peserta didik perlu adanya langkah terencana dan efektif dalam optimalisasi fungsi pendidikan dalam rangka mencerdaskan bangsa sebagai sumber daya dalam pembangunan nasional.

Hal yang paling operasional dalam mewujudkan fungsi tadi adalah peningkatkan hasil belajar siswa. Peningkatan hasil ini diperlukan peran guru kreatif yang dapat membuat pembelajaran menjadi lebih baik, menarik dan disukai oleh peserta didik. Suasana kelas perlu direncanakan dan dibangun sedemikian rupa dengan menggunakan model pembelajaran yang tepat agar siswa dapat memperoleh kesempatan untuk berinteraksi satu sama lain sehingga siswa dapat memperoleh hasil belajar yang optimal.

Salah satu upaya yang dapat dilakukan untuk meningkatkan hasil belajar siswa adalah penggunaan strategi yang tepat serta penggunaan media secara efektif untuk mempertinggi kualitas yang akhirnya dapat meningkatkan kualitas prestasi belajar.

Adanya strategi menjadikan proses pembelajaran lebih terarah dan sistematis. Pemilihan pendekatan dan metode pembelajaran merupakan faktor yang sangat penting dalam proses pembelajaran, sebab disamping untuk pencapaian tujuan juga harus mempertimbangkan karakteristik dan setting pembelajaran tersebut.

Banyak strategi pembelajaran yang dapat merangsang siswa untuk aktif, kreatif dan 
inovatif dalam mengikuti kegiatan pembelajaran. Salah satu alternatif strategi pembelajaran yang bisa digunakan dalam pembelajaran adalah strategi scaffolding. Dalam strategi scaffolding siswa didorong untuk belajar melalui keterlibatan aktif mereka sendiri. Siswa mendapat bantuan atau bimbingan dari guru pada awal pembelajaran agar mereka lebih terarah sehingga proses pelaksanaan pembelajaran maupun tujuan yang dicapai terlaksana dengan baik. Bimbingan guru yang dimaksud adalah memberikan bantuan secara bertahap kepada siswa agar dapat mengikuti proses pembelajaran dengan baik.

Scaffolding merupakan jembatan yang digunakan untuk menghubungkan apa yang sudah diketahui oleh siswa dengan sesuatu yang baru akan diketahui oleh siswa. Vygostky (dalam Priyatni, 2008) menyatakan bahwa tingkat perkembangan kemampuan anak itu berada pada dua tingkatan/level, yaitu tingkatan kemampuan aktual (yang dimiliki anak) dan tingkatan kemampuan potensial (yang bisa dikuasai anak). Zona antara tingkat aktual dan potensial itu disebut dengan zone of proximal development (ZPD).

Startegi scaffolding dapat digunakan sebagai upaya peningkatan kualitas proses belajar mengajar, sehingga siswa memiliki kemampuan dalam memahami konsep materi, sikap positif juga keterampilan. Menurut Vygotsky (dalam Jamaris, 2013) bahwa dalam konsep scaffolding seharusnya diberikan tugastugas yang kompleks, sulit dan realistik, kemudian diberikan bantuan yang secukupnya untuk menyelesaikan tugas-tugas tersebut. Namun siswa bukan diajar sedikit demi sedikit komponen-komponen materi pembelajaran, tetapi diberian suatu tugas yang kompleks sehingga pada suatu hari diharapkan terwujud menjadi suatu kemampuan untuk menyelesaikan tugas kompleks tersebut.

Strategi scaffolding yang disusun dalam penelitian ini memiliki beberapa ketentuan, dimana siswa dituntut untuk belajar mandiri secara berkelompok dengan bantuan mutimedia pembelajaran. Pembelajaran secara berkelompok dengan menggunakan multimedia ini dimaksudkan untuk mendorong para siswa menjadi lebih aktif dalam kegiatan belajar mengajar, karena peran guru disini hanya sebagai fasilitator saja, dimana semua kegiatan pembelajaran telah ditanamkan di dalam multimedia yang telah dibuat.
Munir (2012:138) mengatakan bahwa teknologi multimedia telah menjanjikan potensi besar dalam merubah cara seseorang untuk belajar, untuk memperoleh informasi, menyesuaikan informasi, dan sebagainya. Multimedia juga menyediakan peluang bagi pendidik untuk mengembangkan teknik pembelajaran yang digunakan sehingga menghasilkan hasil yang maksimal. Menurut Munir (2012:7), multimedia memberikan nuansa baru dalam perolehan informasi melaui aktifitas belajar.

Materi pembelajaran berbentuk multimedia dapat memberikan manfaat, yaitu mempermudah dalam penangkapan informasi. Kelengkapan media yang dimiliki teknologi multimedia meliputi seluruh indera yang memang sangat diperlukan dalam proses pembelajaran. Teknologi multimedia dapat berkemampuan untuk mengembangkan daya imajinasi, kreativitas, dan emosi peserta didik ke arah yang lebih baik. Hamalik (dalam Rahman, 2013) menyatakan bahwa pemanfaatan media dalam pembelajaran dapat meningkatkan keinginan dan minat baru, meningkatkan motivasi dan rangsangan kegiatan belajar dan bahkan berpengaruh secara psikologis terdapat siswa. Berdasarkan uraian tersebut, peneliti tertarik untuk meneliti tentang penerapan strategi scaffolding untuk meningkatkan hasil belajar siswa pada pembelajaran Pemrograman Web di SMK Kartika Wirabuana 1.

Berdasarkan hasil wawancara dengan ketua jurusan Teknik Komputer Jaringan (TKJ) di SMK Kartika Wirabuana 1 pada tanggal 10 Februari 2015, hasil belajar siswa yaitu sekitar $16 \%$ dari jumlah siswa mendapatkan nilai dibawah Kriteria Ketuntasan Minimal (KKM) yang berlaku, yaitu 2,66 (B-). Selain itu, tidak seorangpun siswa mendapatkan nilai maksimal. Oleh karena itu, dengan penerapan strategi scaffolding diharapkan dapat membantu siswa lebih aktif dalam pembelajaran.

Mamin, 2008 menyatakan Scaffolding merupakan praktik yang berdasarkan pada konsep Vygotsky tentang zona of proximal development (zona perkembangan proximal). Menurut Vygotsky, siswa mempunyai dua tingkat perkembangan yaitu tingkat perkembangan aktual dan tingkat perkembangan potensial. Tingkat perkembangan didefinisikan sebagai pemungsian intelektual individu saat ini dan kemampuan untuk belajar sesuatu yang khusus atas kemampuannya sendiri. Individual juga 
mempunyai tingkat perkembangan, dimana Vygotsky mendefinisikan sebagai tingkat seorang individu dapat memfungsikan atau mencapai tingkat itu dengan bantuan orang lain seperti guru, orang tua atau teman sebaya yang kemampuannya lebih tinggi.

Zona antar tingkat perkembangan aktual siswa diatas tingkat perkembangan aktual siswa saat ini disebut zona perkembangan proximal (Zona of Proximal Development). Menurut Parson (dalam Mamin, 2008), zona perkembangan terdekat adalah tingkat perkembangan sedikit di atas tingkat perkembangan saat ini. Perkembangan pembentukan (Scaffolding), peran interaksi sosial mendominasi pembentukan mental siswa dimana guru dapat berfungsi sebagai pengingat dan mendukung siswa dalam mendapatkan mental yang lebih tinggi dalam menyelesaikan masalah yang dihadapi siswa. Tingkatan pengetahuan atau pengetahuan berjenjang disebut sebagai Scaffolding.

Istilah scaffolding (perancahan) seringkali digunakan saat orang dewasa atau individu yang lebih kompeten memberikan sejumlah bimbingan atau arahan yang membantu anak melakukan tugas-tugas dalam zona perkembangan proksimal (Zone of Proximal Development/ZPD) mereka. Scaffolding (perancah) adalah perangkat yang berfungsi sebagai penyanggah (tempat berpijak) bagi para pekerja bangunan hingga bangunan itu sendiri telah cukup kuat untuk menyanggah mereka. Saat kestabilan bangunan meningkat, perancah menjadi kurang diperlukan dan akhirnya secara berangsur-angsur dilepaskan (Ormrod, 2008:63).

Serupa dengan ilustrasi di atas, seorang dewasa yang membimbing seorang anak mengerjakan suatu tugas mumngkin memberikan semacam perancah untuk mendukung upaya-upaya awal anak. Dalam dialog guru-siswa mengenai soal pembagian (gambar) yang disajikan sebelumnya, guru memberikan petunjuk mengenai cara mengerjakan soal. Dengan kata lain, scaffolding berkaitan dengan cara atau berbagai interaksi positif yang dilakukan oleh orang dewasa atau teman sebaya dalam memberikan bantuan pada anak yang sedang dalam proses belajar untuk mencapai kematangan dalam tugas-tugas perkembangannya atau dalam mempelajari bidang-bidang tertentu.

Scaffolding berfungsi sebagai bantuan yang diberikan pada anak dalam mengkonstruksi kemampuan yang sedang dikembangkannya. Bantuan yang diberikan melalui interaksi sosial yang dilakukan secara aktif oleh orang dewasa atau teman sebaya yang memiliki kemampuan yang sesuai dengan kemampuan yang berada di dalam area zona perkembangan proximal (ZPD). Bantuan dapat diberikan dalam berbagai bentuk, antara lain melalui; petunjuk atau penjelasan, model atau contoh, pengajuan berbagai pertanyaan, pengembangan strategi dan berbagai bantuan lainnya yang berguna dalam menyelesaikan tugas belajar atau masalah yang dihadapinya secara mandiri (Jamaris, 2013:145).

\section{METODE PENELITIAN}

Penelitian pre-ekperimental karena dalam penelitian ini tidak menggunakan kelas kontrol.Sesuai dengan jenis penelitian yang digunakan, maka digunakan group pretestposttest design. Dalam desain ini, sebelum perlakuan diberikan terlebih dahulu diberi pretest (tes awal) dan di akhir pembelajaran diberi posttest (tes akhir). Desain ini digunakan sesuai dengan tujuan yang hendak dicapai yaitu ingin mengetahui ada tidaknya pengaruh akibat penerapan strategi scaffolding dalam pembelajaran pemrograman web. Penggunaan one group pretest-posttest design terdapat pretest sebelum diberi perlakuan, hasil perlakuan dapat diketahui dengan lebih akurat, karena dapat membandingkan dengan keadaan sebelum diberi perlakuan.

Instrumen yang digunakan dalam penelitian ini berupa tes pilihan ganda. Pretest (tes awal) diberikan untuk mengetahui bagaimanahasil belajar siswa sebelum diterapkan strategi scaffolding.Kemudian Posttest (tes akhir) diberikan dengan maksud mengetahui dan mengukur pemahaman siswa tentang materi yang telah diajarkan dengan menggunakan strategi scaffolding. Butir-butir pertanyaan dalam tes ini disusun dalam bentuk pilihan ganda dengan kriteria penilaian, jika jawaban benar diberi nilai 1 dan jika salah diberi nilai 0. Selain itu siswa diberi angket yang bertujuan untuk mengetahui respon siswa terhadap psoses pembelajaran menggunakan strategi scaffolding yang selanjutnya akan diuji validitas dengan menggunakan rumus korelasi product moment serta Koefisien Alpha Cronbach untuk menguji tingkat reliabilitas angket.

Data yang diperoleh dalam penelitian ini dianalisis menggunakan teklnik analisis statistik deskriptif yang digunakan untuk 
mendekripsikan karakteristik skor dari sampel penelitian untuk variabel dalam hal ini digunakan skor minimum dan maksimum, urutan gejala pusat (mean, median, modus, range), standar deviasi, tabel distribusi frekuensi, dan histogram.

\section{HASIL \& PEMBAHASAN}

Kegiatan penelitian yang dilakukan memberikan angket setelah diterapkan strategi scaffolding dalam pembelajaran pemrograman web pada kelas 10 TKJ 1 dan kelas 10 TKJ 2 SMK Kartika Wirabuana 1, guna untuk mengetahui respon siswa terhadap perlakuan (treatment) yang telah diberikan. Dari data penelitian diperoleh perhitungan dasar statistik sebagai berikut.

Tabel 1. Nilai Statistik Data Angket

\begin{tabular}{cc}
\hline Statistik & Nilai \\
\hline $\mathrm{N}$ & 74 \\
Mean & 72,72 \\
Median & 74,00 \\
Mode & 75 \\
Std. Deviation & 6,765 \\
Range & 28 \\
Minimum & 58 \\
Maximum & 86 \\
\hline
\end{tabular}

Adapun bentuk persentase dari hasil analisis deskriptif angket berdasarkan data statistik di atas dapat dilihat pada tabel 2 berikut:

Tabel 2. Distribusi Frekuensi dan Persentase Hasil Analisis Deskriptif Tentang Respon Siswa

Terhadap Penerapan Strategi Scaffolding dalam Pembelajaran Pemrograman Web

\begin{tabular}{cccc}
\hline Nilai Interval & Kategori & Frekuensi & Persentase (\%) \\
\hline $82-100$ & Sangat Baik & 5 & 6,76 \\
$63-81$ & Baik & 63 & 85,13 \\
$44-62$ & Kurang & 6 & 8,11 \\
$25-43$ & Sangat Kurang & 0 & 0,00 \\
\hline Jumlah & & 74 & $\mathbf{1 0 0 \%}$
\end{tabular}

Sumber: Hasil Olah Data, 2016

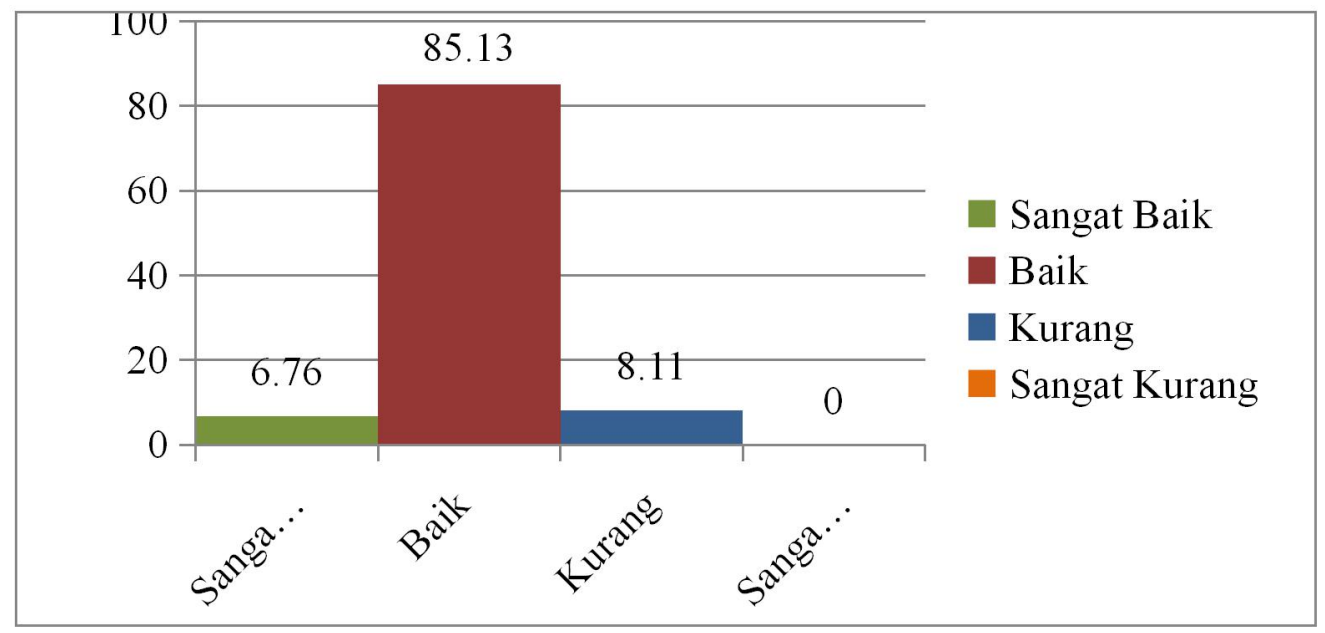

Gambar 1 Histogram Hasil Analisis Statistik Angket 
Berdasarkan tabel 2 menunjukkan bahwa dari hasil analisis angket, pada kategori sangat baik memiliki persentase $6.76 \%$ dengan jumlah responden 5, pada kategori baik memiliki persentase $85,13 \%$ dengan jumlah responden 63, pada kategori kurang memiliki persentase $8,11 \%$ dengan jumlah responden 6 dan pada kategori sangat kurang memiliki persentase $0,00 \%$ karna tidak ada responden yang berada pada kategori tersebut. Hal ini dapat pula dilihat pada gambar 1 histogram hasil analisis statistik angket. Berdasarkan data yang telah diolah dapat disimpulkan bahwa hasil angket tentang respon siswa terhadap penerapan strategi scaffolding dalam proses pembelajaran pada mata pelajaran pemrograman web berada dalam kategori baik.

Selanjutnya adalah kegiatan penelitian yang dilakukan terdiri dari pre-test, treatment, dan post-test. Pertemuan pertama dilakukan tes awal kemudian pada pertemuan terakhir dilakukan tes akhir. Analisis data dimaksudkan untuk mengetahui perbedaan hasil belajar pretest dan post-test.Dari data penelitiandiperoleh perhitungan dasar statistik sebagai berikut.

Tabel 3. NilaiStatistik Data Hasil Belajar Pretest dan Posttest

\begin{tabular}{|c|c|c|}
\hline Statistik & Pretest & Posttest \\
\hline N & 74 & 74 \\
\hline Mean & 1,684 & 2,924 \\
\hline Median & 1,800 & 3,000 \\
\hline Mode & 1,8 & 2,8 \\
\hline Std. Deviation & 0,5440 & 0,4413 \\
\hline Range & 2,4 & 2,4 \\
\hline Minimum & 0,4 & 1,4 \\
\hline Maximum & 2,8 & 3,8 \\
\hline
\end{tabular}

Berdasarkan tabel 3 menunjukkan bahwa jumlah subjek penelitian adalah 74 orang, ratarata hasil pre-test sebesar 1,68 sedangkan ratarata hasil post-test sebesar 2,92, median hasil pre-test adalah 1,800 sedangkan median hasil post-test adalah 3,000, modus pada hasil pretest adalah 1,8 sedangkan pada hasil post-test adalah 2,8, standar deviasi hasil pre-test sebesar 0,544 sedangkan standar deviasi hasil post-test sebesar 0,441 ,range hasil pre-test dan posttest adalah sama yaitu 2,4, skor tertinggi hasil pre-test sebesar 2,8 sedangkan skor tertinggi hasil post-test adalah 3,8. Dan skor terendah hasil pre-test sebesar 0,4 sedangkan skor terendah hasil post-test adalah 1,4. Dari data di atas jika dibuat diagram perbandingan nilai pretest dan postest adalah sebagai berikut:

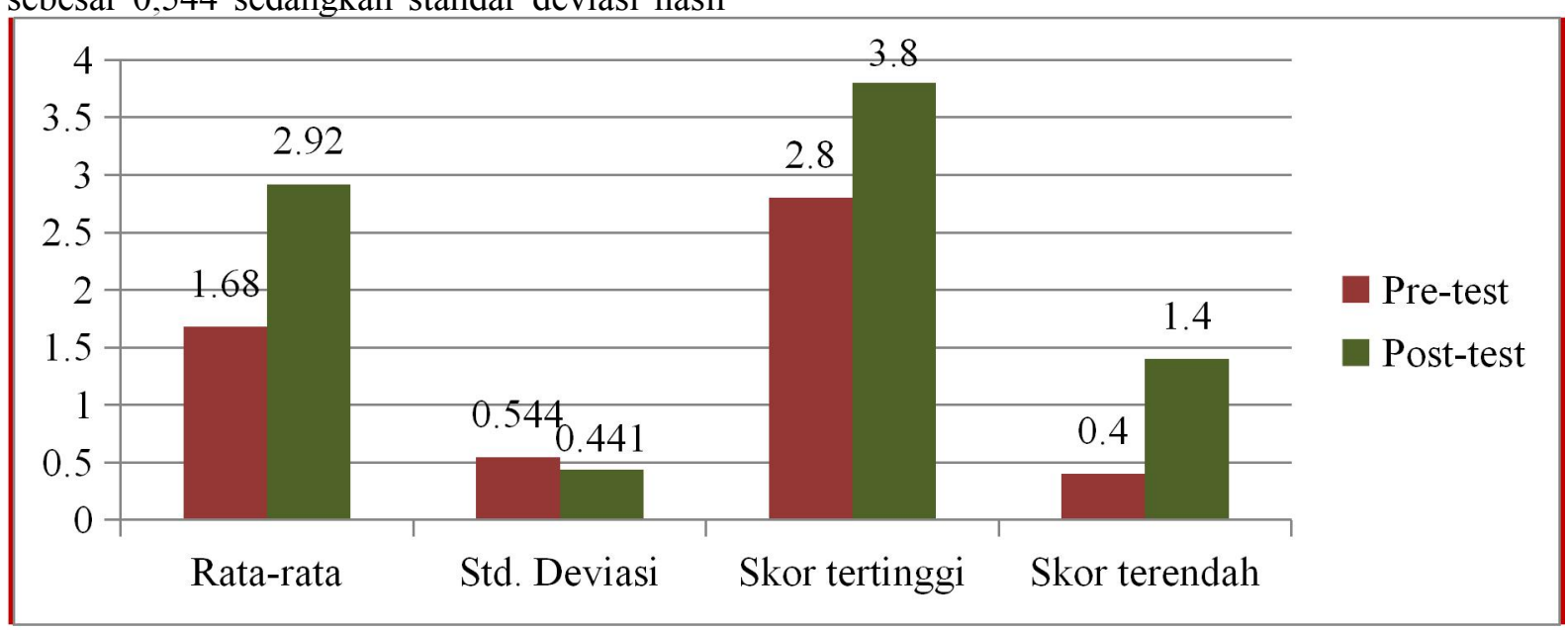

Gambar 2

Diagram Perbandingan Nilai Pre-test dan Post-test 
Dari data di atas diketahui ada peningkatan hasil belajar siswa, dimana nilai rata-rata pretest yang tadinya 1,68 meningkat menjadi nilai rata-rata postest 2,92. Dengan demikian, maka penerapan strategi scaffolding dalam pembelajaran pemrograman web dapat mempengaruhi hasil belajar siswa

Tabel 4

Distribusi Data Sebelum Perlakuan (Pre-test)

\begin{tabular}{|c|c|c|c|}
\hline Interval & Kategori & Frekuensi & Persentase (\%) \\
\hline $3,1-4,0$ & Sangat Tinggi & 0 & 0,00 \\
\hline $2,1-3,0$ & Tinggi & 12 & 16,22 \\
\hline $1,1-2,0$ & Cukup & 51 & 68,92 \\
\hline $0-1,0$ & Rendah & 11 & 14,86 \\
\hline Jumlah & & 74 & $\mathbf{1 0 0} \%$ \\
\hline
\end{tabular}

Sumber: Hasil Olah Data, 2016

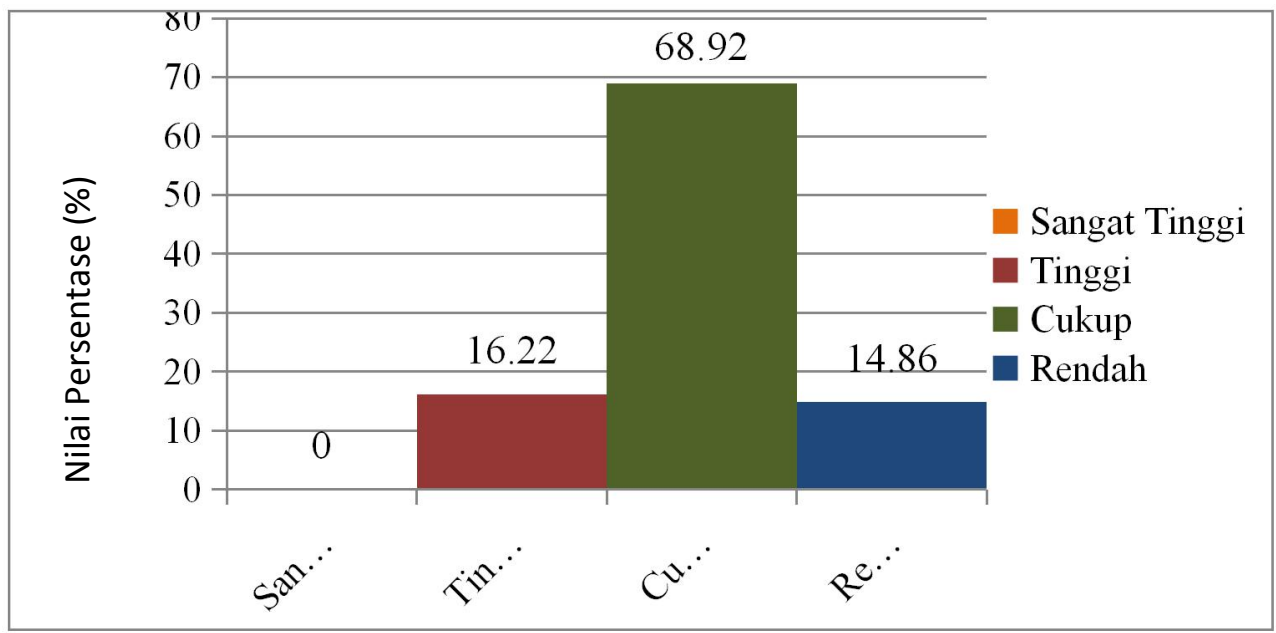

Gambar 3

Histogram Hasil Analisis Nilai Pretest

Berdasarkan Tabel 4 menunjukkan bahwa dari hasil belajar pretest, tidak ada siswa yang berada pada kategori sangat tinggi, pada kategori tinggi memiliki persentase $16,22 \%$ dengan jumlah responden 12, pada kategori cukup memiliki persentase68,92\% dengan jumlah responden 51, dan pada kategori rendah memiliki persentase $14,86 \%$ dengan jumlah responden 11. Hal ini dapat pula dilihat pada Gambar 3 Histogram Hasil Analisis Nilai Pretest. Dengan demikian dapat disimpulkan bahwa hasil pretest berdasarkan data yang telah diolah berada dalam kategori cukup.

Tabel 5

Distribusi Data Setalah Perlakuan (Post-Test)

\begin{tabular}{|c|c|c|c|}
\hline Interval & Kategori & Frekuensi & $\begin{array}{c}\text { Persentase } \\
(\%)\end{array}$ \\
\hline $3,1-4,0$ & Sangat Tinggi & 25 & 33,78 \\
\hline $2,1-3,0$ & Tinggi & 43 & 58,11 \\
\hline $1,1-2,0$ & Cukup & 6 & 8,11 \\
\hline $0-0,1$ & Rendah & 0 & 0,00 \\
\hline Jumlah & & & $\mathbf{1 0 0} \%$ \\
\hline
\end{tabular}

Sumber: Hasil Olah Data, 2016 


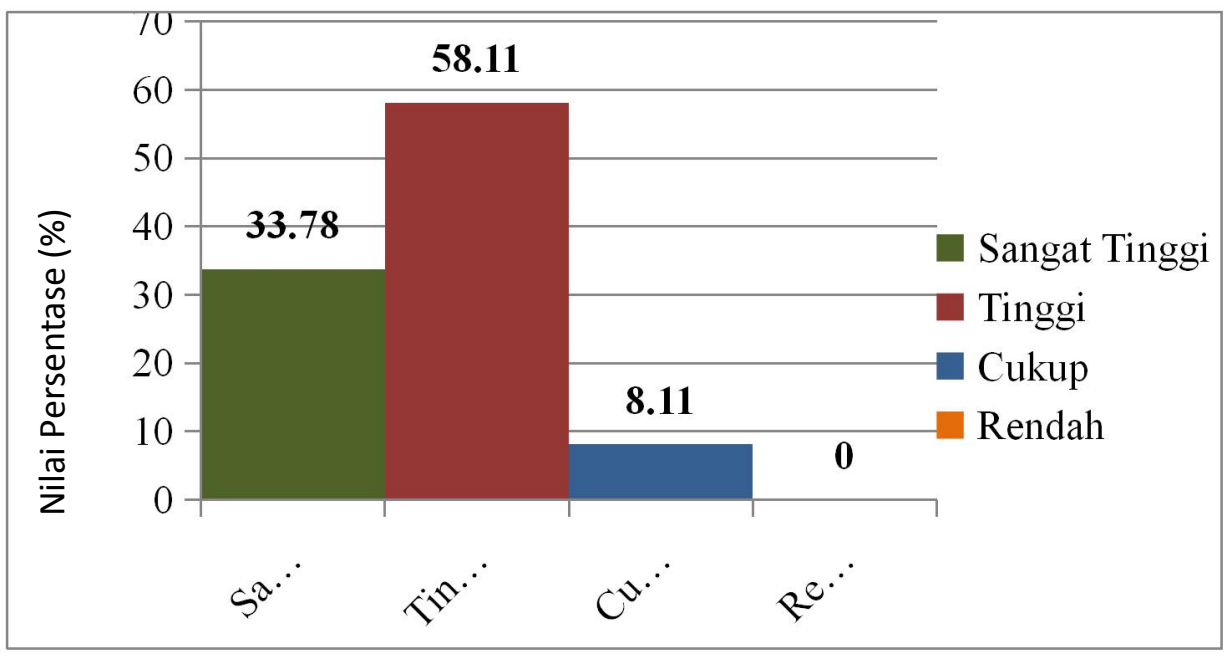

Gambar 4.4

Histogram Hasil Analisis Nilai Post-Test

Berdasarkan Tabel 4.5 menunjukkan bahwa dari hasil belajar posttest, kategori sangat tinggi memiliki persentase 33,78\% dengan jumlah responden 25, pada kategori tinggi memiliki persentase $58,11 \%$ dengan jumlah responden 43, pada kategori cukup memiliki persentase $8,11 \%$ dengan jumlah responden 6 , dan tidak ada siswa yang berada pada kategori rendah. Hal ini dapat pula dilihat pada Gambar 4.4 Histogram Hasil Analisis Nilai Post-test. Dengan demikian dapat disimpulkan bahwa hasil pretest berdasarkan data yang telah diolah berada dalam kategori tinggi.

Penelitian ini dilakukan untuk mengetahui respon siswa terhadap penerapan strategi scaffolding dalam proses pembelajaran pada mata pelajaran pemrograman web dan untuk mengetahui bagaimana hasil belajar siswa setelah diterapkan strategi scaffolding. Untuk mengetahui hasil belajar siswa, dalam penelitian ini dilakukan menggunakan model one group pretest posttestdesign yang berarti sebelum perlakuan diberikan terlebih dahulu diberi pretest (tes awal) dan di akhir pembelajaran diberi posttest (tes akhir). Penggunaan desain ini berbeda dengan desain lainnya karena seluruh objek penelitian diberikan perlakuan (treatment) tanpa adanya kelas kontrol dan kelas eksperimen. Sedangkan untuk megetahui respon siswa terhadap perlakuan yang telah diberikan, digunakan instrumen angket.

Berdasarkan hasil analisis angket, dapat dilihat bahwa secara umum respon siswa terhadap penerapan strategi scaffolding sudah berada dalam kategori baik. Penilaian siswa tersebut terdiri dari segi penggunaan strategi scaffolding, tampilan multimedia dan isi materi dalam multimedia. Terdapat empat alternative jawaban pada pernyataan angket untuk memberikan penilaian siswa terhadap perlakuan yakni Sangat Setuju, Setuju, Tidak Setuju dan Sangat Tidak Setuju. Dari 74 orang, 63 dari mereka memberikan respon Setuju dan Sangat Setuju terhadap butir-butir pernyataan angket. Adapun nilai rata-rata skor angket dari 74 orang sampel yaitu 72,72. Dari hasil analisis statistik skor angket menunjukkan bahwa siswa memberikan respon yang baik atau positif terhadap penerapan strategi scaffoldingdalam pembelajaran pemrograman web.

Pengaruh penerapan strategi scaffolding dalam pembelajaran pemrograman web dapat dilihat dari hasil belajar pretestdan posttest.Untuk melihat tingkatan hasil belajar siswa digunakan pengkategorian yang terdiri dari 4 kategori yaitu sangat tinggi, tinggi, cukup dan rendah. Berdasarkan analisis statistik menjukkan bahwa hasil belajar pretest berada pada kategori cukup dimana kategori tesebut diukur dengan melihat nilai maksimum dan nilai minimum skor hasil belajar siswa. Pretest tersebut diberikan kepada siswa pada awal pembelajaran yang terdiri dari 20 nomor soal. Rata-rata nilai pretest adalah 1,684. Kemudian postest diberikan untuk melihat hasil belajar siswa setelah diterapkan perlakuan yang terdiri dari 20 nomor soal. Hasil belajar postest berada pada kategori tinggi karena paling banyak siswa memiliki skor hasil belajar yang pada kategori tersebut. Sedangkan pada kategori cukup hanya terdapat 
6 orang. Adapun nilai rata-rata posttest adalah 2,924.

Berdasarkan hasil analisis tes menunjukkan bahwa penggunaan strategi scaffolding dalam pembelajaran pemrograman web berpengaruh positif terhadap hasil belajar siswa. Hal tersebut juga dapat dilihat dari perbedaan rata-rata yang menunjukkan bahwa rata-rata hasil belajar postest lebih besar dari rata-rata hasil belajar pretest.

\section{KESIMPULAN \& SARAN}

Berdasarkan hasil penelitian dan pembahasan hasil penelitian tentang pembelajaran yang dilakukan dengan menggunakan strategi scaffolding, untuk melihat respon siswa dan pengaruhnya terhadap hasil belajar siswa kelas 10 TKJ 1 dan 10 TKJ 2 SMK Kartika Wirabuana 1, maka dapat disimpulkan bahwa:

a. Dari hasil analisis deskriptif angket dapat diketahui bahwa siswa memiliki respon baik terhadap penerapan strategi scaffolding dalam pembelajaran. Ini berarti strategi yang digunakan dapat diterapkan dalam pembelajaran pemrograman web.

b. Dari hasil analisis deskriptif tes menunjukkan bahwa penerapan strategi scaffolding dalam pembelajaran pemrograman web mempengaruhi hasil belajar siswa.Hal itu ditandai dengan adanya peningkatan rata-rata nilai hasil tes siswa yaitu rata-rata nilai hasil posttest adalah 2,92.

Penelitian ini belum maksimal mengungkapkan pengaruh penerapan strategi scaffolding dalam pembelajaran sehingga diharapkan peneliti lain dapat memperdalam penelitian ini. Untuk guru mata pelajaran pemrograman web diharapkan agar mengikuti pelatihan untuk menggunakan strategi scaffolding dalam melaksanakan pembelajaran agar memudahkan proses pembelajaran serta membangkitkan minat dan semangat belajar siswa sehingga dapat meningkatkan hasil belajar siswa.

\section{DAFTAR PUSTAKA}

Anjani, Lavia. 2013. Peningkatan Kemampuan Komunikasi Matematis Menggunakan Pendekatan Kontekstual dengan Teknik Scaffolding, (on line), (http://repository.upi.edu/3279/2/S MTK
0901962 Abstract.pdf, diakses

29 Januari 2015).

Arikunto, Suharsimi. 2010. Prosedur Penelitian Suatu Pendekatan Praktik (Edisi Revisi). Jakarta: Rineka Cipta.

Biyobe, Wahid. 2013. Pengertian Hasil Belajar, (online), (http://wahidbiyobe.blogspot.com/2013/05/pengertiandan-arti-penting-spesifik.html. diakses 6 Maret 2015).

Hamalik, Oemar. 2004. Proses Belajar Mengajar. Jakarta: PT Bumi Aksara.

Jamaris, Martini. 2013. Orientasi Baru dalam Psikologi Pendidikan. Bogor: Ghalia Indonesia.

Kasmadi \& Sunariah, Nia Siti. 2013. Panduan Modern Penelitian Kuantitatif. Bandung: Alfabeta.

Mamin, Ratnawati. 2008. Penerapan Metode Pembelajaran Scaffolding pada Pokok Bahasan Sistem Periodik Unsur. Jurnal Chemica, (on line), Vol.10, nomor 2, (http://download.portalgaruda.org/article. php? article $=57819 \&$ val $=4338$, diakses 15 Januari 2015).

Munadi, Yuhdi. 2013. Media Pembelajaran Sebuah Pendekatan Baru. Jakarta: Referensi (GP Press Grup).

Munir. 2012.Multimedia Konsep \& Aplikasi dalam Pendidikan. Bandung: CV Alfabeta.

Murod, Rofiq Robithulloh. 2013.Pendekatan Pembelajaran Metacognitive Scaffolding Dengan Memanfaatkan Multimedia Interaktif Untuk Meningkatkan Literasi Matematis Siswa SMA, (on line), (http://repository.upi.edu/id/eprint/3019, diakses 30 Januari 2015).

Ormrod, Jeanne Ellis. 2008. Psikologi Pendidikan Membantu Siswa Tumbuh dan Berkembang. Jakarta: Erlangga.

Priyatni, Endah Tri. 2008.Peningkatan Kompetensi Menulis Paragraf dengan Teknik Scaffolding, (on line),(http://sastra.um.ac.id/wp-content/ uploads/2009/10/Peningkatan-

Kompetensi-Menulis-Paragraf-denganTeknik-Scaffolding-Endah-TriPriyatni.pdf, diakses 20 Januari 2015).

Rahman, Muhammad \& Sofan Amri. 2013. Strategi \& Desain Pengembangan Sistem Pembeljaran. Jakarta: Prestasi Pustakaraya.

Rusman, 2010. Model Model Pembelajaran Mengembangkan Profesionalisme Guru. Jakarta: PT RajaGrapindo Persada. 
Subana \& Rahadi, Moersetyo. 2000. Statistik Pendidikan. Bandung: Pustaka Setia.

Sudjana, Nana. 2004. Penilaian Hasil Belajar Mengaja. Bandung : Rosdakarya

Sugiyono. 2007. Metode Penelitian Pendidikan Pendekatan Kuantitatif, Kualitatif, dan $R \& D$. Bandung: Alfabeta.

Sumoharjo, Addy. 2012. Defenisi Konsep Hasil Belajar. (online), (http://addyarchy07.blogspot.com/2011/1 2/definisi-konsep-hasil-belajar.html. diakses 11 Januari 2014 